This item was submitted to Loughborough's Research Repository by the author.

Items in Figshare are protected by copyright, with all rights reserved, unless otherwise indicated.

\title{
Building inclusive nations in the age of migration
}

PLEASE CITE THE PUBLISHED VERSION

http://dx.doi.org/10.1080/1070289X.2016.1148607

\section{PUBLISHER}

(c) Taylor \& Francis

\section{VERSION}

AM (Accepted Manuscript)

\section{PUBLISHER STATEMENT}

This work is made available according to the conditions of the Creative Commons Attribution-NonCommercialNoDerivatives 4.0 International (CC BY-NC-ND 4.0) licence. Full details of this licence are available at: https://creativecommons.org/licenses/by-nc-nd/4.0/

\section{LICENCE}

CC BY-NC-ND 4.0

\section{REPOSITORY RECORD}

Antonsich, Marco, Elizabeth Mavroudi, and Sabina Mihelj. 2019. "Building Inclusive Nations in the Age of Migration". figshare. https://hdl.handle.net/2134/21001. 


\title{
Building Inclusive Nations in the Age of Migration
}

\author{
Marco Antonsich, Liz Mavroudi, and Sabina Mihelj \\ Loughborough University
}

\begin{abstract}
:
Nation and diversity are often casted in oppositional terms. The present joint-intervention explores the limits and possibilities of what we call 'inclusive nation', i.e. a nation which embraces rather than expunging diversity. To reflect on this idea, the Loughborough University Nationalism Network (LUNN) organized a symposium, bringing together both academics and relevant stakeholders, to explore both theoretically and practically the feasibility of the inclusive nation. For reason of space, here we present only the theoretical views of academics. While Billig and Yuval-Davis highlight the inherent exclusive thrust of nationalism, Kaufmann and Hearn suggest two distinct ways to move away the traditional understanding of nationalism as a site of singularity, oppression and exclusion. A final rejoinder by Nyhagen pushes the debate further interrogating the boundaries of national belonging.
\end{abstract}

Key-words: nation, diversity, migration, belonging

In the present age of migration, transnational paradigms have gained momentum, often dismissing the nation-state as something historically obsolete and politically questionable (Soysal 1994, Wimmer and Glick Schiller 2002). Yet, despite important insights from this scholarship, social and political life remains largely structured by discourses, practices, and institutions articulated at the national scale (Mihelj 2011, Antonsich and Matejskova 2015a). This is even more so today, when a re-nationalization process seems to characterize the public response to a variety of 'crises’ (e.g. financial, migratory, terrorist and European). Thus, rather than wishing the national away, it is important to understand the ways in which this register continues to intervene, both discursively and practically, in the shaping of individual and collective life.

To examine the continued relevance of the national in contemporary societies, the Loughborough University Nationalism Network (LUNN), a recently constituted 
interdisciplinary research group, convened a one-day workshop, which took place in September 2014 at Loughborough. It brought together a group of academics (Nira YuvalDavis, Michael Billig, Eric Kaufmann and Jonathan Hearn) and a group of representatives of governmental and non-governmental organizations concerned with issues of equality and diversity in Britain (Equality and Human Rights Commission; Migrants’ Rights Network; Accord Coalition; East Midlands Strategic Migration Partnership; The Race Equality Centre; Equalities at Leicester City Council,; Equality and Diversity at Nottingham City Council,; Equalities, Community Safety and Cohesion at Birmingham City Council). The participants were invited to engage with the idea of an inclusive nation, one that offers a sense of belonging and identity yet also accommodates difference. In a context of increasing ethnocultural and religious diversity, spurred by international migration (Alba and Foner 2014), the question about how to generate such inclusive nation remains very urgent for many Western democracies. Yet, is such a nation possible, and if so, how can we go about conceptualizing and fostering it?

The aim of the workshop was both to start a scholarly conversation on this issue and to build a bridge between theoretical reflection and work 'on the ground'. In this contribution, we focus on the first aim, and bring together the perspectives of our invited academic colleagues, which offer a useful platform for reflecting on the limits and possibilities of the idea of an inclusive nation. While Billig and Yuval-Davis’s contributions are marked by a good dose of skepticism, Kaufmann and Hearn are more open to the idea of inclusive nation, and point to possible theoretical approaches to the issue. To reconcile these positions and push the reflection further, we then asked our LUNN colleague Line Nyhagen to offer a final rejoinder. We hope that this joint intervention will serve the purpose of stimulating a reflection on two key terms - nation and diversity - which are usually perceived as mutually exclusive (Mavroudi 2010, Antonsich and Matejskova 2015b). Yet, we would argue that this 
very opposition ends up reifying the nation as the exclusive domain of xenophobic and ethnoculturalist discourses, obliterating the spaces, contexts, and happenings of alternative understandings of nation. While we do not deny that the nation can, and very often is, mobilized as a category of exclusion, we should be wary of limiting ourselves to this reading only. Such a narrow reading would obliterate other constellations of diversity and nation, including the numerous ways in which diversity can enter and reshape the meaning of the nation itself (Modood 2007, Papademetriou 2012, Bloemraad 2014).

\section{Nationalism, exclusion and inclusion}

Michael Billig

Loughborough University

I should begin by admitting that I have not studied nationalism for a number of years. My invitation to contribute to this forum stems from a book which I wrote twenty years ago (Billig, 1995). I have not kept up with recent academic developments in the study of nationalism nor with new trends in the nature of nationalism itself. Recently I have been interested in the language that academic social scientists tend to use (Billig, 2013 and 2015). The world of academia has become increasingly competitive and the phrase 'academic capitalism’ seems to describe present conditions well (Slaughter and Rhoades, 2004 and 2009). We like to think that the language of commerce is very different from the language of scholarship, although we work in highly managed institutions, which treat academic publications as commodities whose monetary value is potentially assessable. It is uncomfortable for academics to admit that self-promotional, marketing language might be 'normal' in the university context. I would like to illustrate this with an example relating to 
the study of nationalism. My example is very close to home - or at least to my academic home - and, in consequence, is doubly uncomfortable.

\section{Nationalism as an everyday ideology}

My previous work on nationalism sought to examine the ideological assumptions of nationalism. Unlike many others who have looked at nationalism, I was not particularly concerned to distinguish between different types of nationalism, such as civic nationalism and ethnic nationalism or inclusive and exclusive nationalism. Nor did Banal Nationalism did confine itself to examining social movements which are self-consciously nationalist and which are dedicated to creating new independent national states. Instead, it examined everyday nationalism, or the markers of nationalism which might be found across different nations. In this regard, the book was neither taking extreme nationalism as the epitome of nationalism in general nor was it seeking to distinguish between the specific forms of nationalism but was looking at more general, ideological features of nationalism.

The notion of ‘ideology’ is crucial. Many years ago, Berger and Luckmann (1967) wrote about "the reality of everyday life”, as people take their own everyday world as being the world, as if has an objective reality. For some analysts, the concept of 'ideology' refers to those beliefs and practices by which the social world, constructed by humans, comes to appear as if it is natural and thereby unchangeable (see, for instance, Eagleton, 2007). To understand nationalist ideology in this sense, it is necessary to go beyond examining this or that set of nationalist beliefs, but to see nationalism as an international ideology that has spread across the globe. Specific nation states, with their histories, laws of citizenship and social myths, do not exist in isolation: they exist within a 'world of nations'. With the exception of Antarctica, it appears 'natural' that all the land-mass of the world should be divided into different nation states. All forms of nationalism, whether those of nation-states 
existing within this world of nations or those of movements struggling to achieve their own national independence, in order to enter this world of nations, take for granted the existence of nations as natural. International treaties, agreements and trading areas can only exist within this 'natural' world of nations. Accordingly, nationalism is globally the dominant form of politics and it represents an international ideology, as it has done since the early formation of nation states in the modern era. Even such a superficially non-national way of organizing politics as the European Union is a union of nations existing within a wider world of nations. Although there may be disputes about where the boundaries between nations should be drawn, or how nations should treat their citizens or award citizenship, there is virtually no dissent from the 'common-sense' belief that the world is 'naturally' divided into separate nations. Thus, the world of nations is taken as ideologically natural.

\section{Problem of inclusion}

What this means is that nations are inherently exclusionary. Whether a nation's residents are treated in an equally inclusive manner or whether some are considered more central than others, it will consider the majority of the world's people to be outsiders. It is of the nature of nations and nation-states that they must necessarily exclude. No nation-state can exist in the world of nations and claim the whole world as its citizens. In practice most, if not all, nation-states have laws which define who is a citizen and who by implication is excluded from citizenship.

The 'naturalness' of this has become apparent in the recent refugee crisis. Millions have fled from their own 'homelands', principally Syria and Afghanistan. They are not seen to belong to any other nation and are not free to choose to belong to another nation. The leaders and citizens of the nations, into which they have fled or which they seek to enter, take it as a 'natural' fact that such people they do not properly belong to any other nation except the one 
from which they have fled. It is 'natural' in this world of nations to identify such refugees by the nation in which they fear to live - as 'Syrians', 'Afghans', 'Somalis'. The leaders of some nations make 'benevolent', 'humanitarian' gestures, saying that their nation will be prepared to admit a few thousand from the millions of these intrinsic outsiders. The majority of refugees have to wait, enduring make-shift tents and harsh climates, until they can be returned to the nation to which they 'naturally' belong. In the world of nations, they are 'naturally', or rather legally and politically, condemned to remain unwanted, excluded outsiders.

All this is backed by an ideology that takes the exclusionary nature of nations to be natural. This is not the product of this nationalism or that nationalism, as if particular forms of nationalism can be blamed for the response from the nations of the world. It stems from the fundamentally exclusive ideology of nationalism tout court.

\section{Academic language}

One might ask how does this relate to issues about academic language. It concerns the balance between the positive term 'inclusion' and the negative term 'exclusion'. As academics, we work in institutions that are increasingly driven by commercial factors. We are constantly encouraged to conduct the sort of research that will enable us to bring research funds to our institutions. University managers warn young academics that they will not obtain promotion unless they obtain sufficient research monies. In consequence, academics have an interest in using the sort of language that attracts grants and this tends to be a language of positives rather than negatives.

My own university has decided to group the university’s research priorities under six 'Research Challenges', favouring projects that fit one or more of these approved challenges. 
Basically, these challenges are phrased in positive language: such as 'Secure and Resilient Societies’, ‘Health and Well-Being’, ‘Communication, Culture and Citizenship’. Negative, or potentially negative terms, such as 'insecurity', 'disease', 'refugee' or other problem terms do not appear in these titles. This cannot be a coincidence. The positive words creates the image of a positive world which the university’s research can help bring about.

The University web-site describes its Research Challenges in positive terms: "These challenges provide a framework for enhancing interdisciplinary research; accelerating the delivery of distinctive solutions to regional, national and international challenges and becoming a catalyst for growth.” (http://www.lboro.ac.uk/research/challenges/). Even the notion of a 'challenge' (rather a 'problem') is itself suitably positive. Who could possibly prefer problems to challenges?

Research into nationalism basically fits the Challenge of 'Communication, Culture and Citizenship’. Here the semantic preference for inclusion over exclusion becomes clear. The opening paragraph describing this Challenge mentions that communication can bring people together and tear them apart and that we need to understand the processes of "inclusion and exclusion”. After the opening paragraph comes ‘Loughborough's Contribution’ and this is where the word ‘exclusion’ gives way to ‘inclusion': “We address the problematics of inclusion..., the performance of inclusion... and the practices of inclusion (the development of innovative strategies, policies and products that promote greater opportunity, equality and participation)." The web-site asserts that "social inclusion is one of the topics around which our expertise clusters.” Semantically ‘exclusion’ itself has become excluded.

This tendency to use optimistic, positive language suggests that problems can be solved, or at least partially solved, with further research. Saying that nationalism is fundamentally exclusive suggests a lack of optimism that the problems of nationalism can be 
resolved without radical change. Political leaders and grant-awarding bodies like to imagine that they are spending money wisely, accomplishing much while changing little.

Accordingly, there are political and financial reasons for using positive language in the necessary pursuit of research funding. In these conditions it is easy to overlook the general exclusive ideology of nationalism; this neglect will itself appear natural and, accordingly, is by its nature ideological.

\section{Inclusive nationalism}

Nira Yuval-Davis

University of East London

The project of inclusive nationalism is virtually impossible to construct on full egalitarian basis, which does not mean, however, that it is not a worthwhile goal to aspire to and engage in. The issue is how to build inclusive convivial national solidarity as a normative aspiration and as a social and political process in practice which would take into account differential social, political and economic power relations and would encompass the situated intersectional gazes of as many segments of society as possible (Yuval-Davis, 2011).

Before discussing national solidarity, however, we need to recognize that such solidarity is always constructed around some kind of assumed boundaries of the nation. These can be more or less inclusive, more or less permeable, but they always divide the world into 'us' and 'them'. Rabindranath Tagore defined nationalism as ‘organized selfishness' (cited in Mishra, 2014) and Lea Greenfeld (1992) described the one characteristic common to all kinds of nationalist ideologies which is that they always see their nation as superior to all others. So the project of 'inclusive nationalism' would always be a bit paradoxical. 
Different theories and projects of nationalism view national solidarity and boundaries as constructed around different themes and developed different typologies. In my work on the politics of belonging (Yuval-Davis, 2011) I demonstrated three different kinds of contested British notions of national solidarity - the Enoch Powell kind, which is constructed around common 'blood' or descent; the Norman Tibbet and his 'cricket test' kind, which is built around emotional and cultural solidarity; and the New Labour one (that David Cameron shares as well), which is constructed around shared values. In the third case, cosmopolitan values such as democracy and respect of human rights are used to demonstrate British superiority vs other nations.

A potentially crucial insight regarding inclusive nationalism has been Otto Bauer’s (2001[1924]) work. Unlike other nationalism theorists who saw national solidarity built around a notion of common origin, Otto Bauer emphasized the notion of common destiny. The notion of common destiny can be seen as a 'natural' outcome of common origin, but it can also be caused as a result of civic and other kinds of unifying ideologies. These can be a crucial focus of contestation in pluralist societies. For instance, in the former Yugoslavia, people lived together comfortably as part of the same village and nation in spite of a common knowledge of different origins and religions. The civil war and the massacres of former neighbours and friends took place when different origins started to signify different zero-sum destinies.

In relation to this I would like to report on an interesting debate which took place in a recent conference that the Centre for Research on Migration, Refugees and Belonging $(\mathrm{CMRB})$ - the research centre I direct - co-organized with SOAS on anti-Jewish and antiMuslim racisms and the question of Palestine/Israel (http://www.uel.ac.uk/cmrb/publications.htm). On one side of the debate were those who argued that it was racism against Jews not to agree with the Zionist demand of the Jewish 
right for self determination and the definition of Israel as a Jewish state. On the other side were those who argued that it was racist to define Israel as a Jewish state because rather than, or not only, has Zionism been a movement for national liberation of the Jews, but it has been a settler colonial society, and all contemporary settler societies - from the USA to South Africa to Australia - do not define their national project around a unitary ethnic, national or religious origin.

Moving back to Europe, in the current refugees’ crisis, it was interesting how the discourse of solidarity crossed national boundaries in different ways, even when not establishing explicitly exclusionary boundaries, as the Hungarian Prime Minister had done, in the name of keeping Hungary - and Europe - Christian. In many of the German and other liberal discourses of solidarity with the refugees, as reported on TV and other media, the key argument was constructed around the notion of the refugees from Syria as deserving solidarity because they are 'people like us' - not just because of their plight. The description always emphasized that most of the Syrian refugees were professionals and other educated middle class people, who would easily assimilate and were fit to belong to their receiving nations. On the other hand, David Cameron's discourse was of a humanist solidarity, based on the 'deserving poor' - the genuine needing refugees in the camps and the disabled - the superior charitable British nation would help the deserving poor who cannot help themselves (unlike those who can and thus arrived to Europe as illegal migrants as no legal routes were open to them). This is a discourse in which the boundaries of belonging are firmly drawn and the assumption is that each nation has its own spatial place on the globe and the least movement (at least in the direction to Britain) the better.

The last point I want to discuss here relates to one of our main findings in the EUBorderscapes research project in which I am involved, leading the work package on ‘everyday bordering'. While part of our work related to people living on and crossing state 
borders - in the UK between Calais and Dover - we also studied everyday bordering in London (we also made a film about this ‘everyday borders' which can be watched here: http://www.uel.ac.uk/news/press-releases/2015/05/-everyday-borders-feature.htm).

In relation to this I want to discuss the paradox that the more securitisation measures are taken in order for everyone living legally in the UK to feel safe and at home where they belong, the more these feelings of safety, comfort and conviviality of living in pluralist multicultural Britain are being undermined, and inclusive constructions of the nation get further away than ever. The task before us is to find a way to make people feel comfortable and safe without destroying trust based on what Durkheim has called pre-contractual solidarity which is a necessary condition for any collective action. In order to do so, we need to encompass into our notion of national inclusivity the situated intersectional gazes of all members of the society and recognize the multi-layered and cross-borders belonging of us all.

\section{From Multiculturalism to Multivocalism: complexity, national identity and political theory}

Eric Kaufmann, Birkbeck College, University of London

I claim national identities in liberal societies increasingly resemble complex adaptive systems (CAS) rather than state-directed collective representations. Complex systems are phenomena, such as flocks of birds or traffic patterns that emerge from the uncoordinated actions of the actors or components underneath. Order emerges from chaos due to the minimal coordination provided by simple rules (i.e. stay a certain distance from the next bird) or mechanisms, such as prices in a market (Urry 2005). No 'lead’ individual imagines the whole much less directs it. 
Recent scholarship in nationalism increasingly privileges the emergence of national identity ‘from below’ as opposed to from state elites ‘above’ (i.e. Edensor 2002; Fox 2014). This chimes well with the complexity model. A central aspect of complexity theory is the principle of distributed information, that the 'brain' of the whole cannot be located in any one component. In guessing the number of beans in a jar, or who will win a horse race, adding up the sum of everyone's guesses and dividing by the number of participants provides an answer nearly as good as the winning guess. The point is that the collective 'wisdom of crowds' cannot be pinned down to any single individual (Surowiecki 2004). This is directly relevant to the conception of national identity insofar as I claim national identity is a complex system that cannot be read off any one individual, institution or document. Class, region, ethnicity, gender and other vantage points act as lenses, focusing a person's attention on particular symbols of the national canon rather than others (Kaufmann 2008). Like Cohen’s (1996) 'personal nationalism', the national identity inheres in the sum of individual experience, in other words, in the whole.

\section{Contemporary Debates in the Normative Political Theory of Nationalism}

Normative theorising of national identity has entered a cul-de-sac, in which proponents of liberal nationalism and multiculturalism face each other from entrenched redoubts. Multiculturalists seek equal public recognition for ethnic communities, which demands that the nation be defined in a 'thin', inoffensive way on the basis of shared universals such as toleration and liberty (Kymlicka 1995; Taylor 1992). Those who champion liberal nationalism urge a 'thicker’ set of symbols and narratives, notably a shared language or history, to inspire democratic participation, social cohesion and the sharing necessary for a welfare state (Miller 1995; Tamir 1993). Liberal nationalists shy away from including exclusive criteria such as majority group ancestry as part of what it means to be a member of 
the nation, but many in fact attach to the nation through their majority ethnicity. For instance, over half the respondents to the British Social Attitudes Survey replied that having British

ancestry was an important part of being British (Park et. al. 2014). Where multiculturalism is insufficiently sensitive to minority demands, liberal nationalism falls short for many in the ethnic majority.

How might the 'wisdom of crowds' help us escape the zero-sum condition in which the political theory of cultural diversity is entangled? The key lies with individuals' and groups' distinctive perspectives on the nation, and hence the rich lode of distributed information that a grasp of complexity can help to unlock.

\section{Complexity and Political Theory: Toward Multinationalism}

Is liberal nationalism the best we can do in a world of competing demands? Certainly, if we limit ourselves to a one-size-fits-all understanding of national identity in which all members of the polity must subscribe to a unitary conception of political identity. Liberal nationalism arguably strikes a more acceptable note for western elites than either multiculturalism or ethnic nationalism, but it fails to satisfy most citizens, who cannot see their conception of the nation fully reflected in it.

Complexity theory contends that national identity is an emergent property of groups and individuals, even as the state is an important voice in the conversation. This means no two individuals glimpse the nation from precisely the same point. Victor Turner used the term multivocal to refer to the multiplicity of meanings a given symbol like the Stars and Stripes may evoke in a population (Turner 1967). Accordingly, a multivocalist ethics of identity avers that information about a nation's identity is distributed among a population. So 
long as the state sets out a minimal set of civic criteria akin to market rules, the detail can be filled in by the interaction of individuals and groups. Nationalism becomes crowdsourced.

The position of the state in this emergent, flexible nationalism is neutral but proactive. Its aim should be to set out a common minimum to which all subscribe: the proper name of the country, its borders, perhaps a lingua franca, and a thin set of values, which in the West involves a generalised respect for liberty, equality and democracy. Under a multivocalist dispensation, the state maintains a stance of 'constructive ambiguity ${ }^{\mathrm{i}}$ which validates a variety of mutually incompatible national visions: ethnic, civic, multicultural. This does not address legal questions such as whether to ban the burqa, or how to placate violent secessionists, but it ministers to much broader symbolic concerns among those seeking to square their ethnic and national identities.

In Northern Ireland, for instance, constructive ambiguity refers to the fact protagonists had divergent political ambitions so framers of a deal needed to be flexible. The architects of the Good Friday Agreement (GFA) sensed that an ambiguously-worded document would permit both Unionist and Nationalist politicians to better sell the agreement to their respective constituencies. Each side could interpret the GFA optimistically, as either a step on the road to a United Ireland (for Nationalists) or, for Unionists, a firmer guarantee of Northern Ireland's place within the United Kingdom (Powell 2008).

A form of constructive ambiguity is a constitutive aspect of many political parties. The result is a high degree of ecological diversity within them. In a decentralised party system like Canada's, constituency associations owe little to central office beyond a common electoral loyalty. This can result in associations with radically different social bases or issue positions coexisting in close proximity (Carty 2002). Within the British Labour party, there are glaring contradictions between the views of traditionalist Muslims, university-educated 
feminists and white-working class trade unionists. Yet so long as these forces are sequestered within different constituency associations - 'franchises' controlled by one or other group their contradictions remain latent and can be contained within the party while focusing diverse actors' energies on a smaller set of shared political objectives. Activists in each branch read what they wish into its brand: they may believe the party stands for their 'thick' values (defense of Muslim concerns, feminism, white working-class culture) guaranteeing party loyalty, even as the only planks which emerge at national level are the 'thin' common denominators such as economic redistribution and opposition to the Conservative Party.

The social movements’ literature likewise recognises the power of flexibility and localism in satisfying diverse actors. Resource mobilisation theory claims that organisations whose structure is decentred to permit maximal diversity of outlook, with considerable discursive (and some policy) leeway devolved to movement branches, are more successful and adaptable. Interpretations of doctrine and strategy are tailored to local conditions, permitting the organisation to harness local knowledge and swiftly respond to changes in the environment.

We have seen that the debate between liberal nationalism and multiculturalism in advanced Western societies lends itself to symbolic solutions, notably a multivocalist approach based on constructive ambiguity. Multivocalism is distinct from multiculturalism because while identities are multiple, these focus on the nation as their reference point rather than the ethnic homeland, thus strengthening social solidarity while allowing scope for diversity. A multivocalist approach also diverges from thin accounts of solidarity such as negative liberalism or constitutional patriotism (Habermas 1992). Though the state is neutral toward most conceptions of the nation, it proactively validates and expresses the rich 
diversity of national identities. By contrast, constitutional patriotism remains restricted to formal constitutional-legal abstractions.

Multivocalism's byword is flexibility, a tailor-made national identity. To return to the British example, a white Briton in a market town may experience a 'thick' Britain seamlessly connected to her English ethnicity; a mixed-race suburbanite may view it as an equally 'thick' melting pot linked to her mixed ancestry, a futuristic nation-in-the-making. Neither readily identifies with multiculturalism. On the other hand, a Somali immigrant in inner London, a Scot or a Welshman might see Britain as a 'thin' outer layer to their identity. For them Britain is a multicultural entity whose cultural reality lies in its parts, even if irreducibly British symbols such as the monarchy and NHS also exist. The 'truth' lies in all three accounts.

If national identity is a complex system that emerges from below, narrow official versions of national identity are bound to be frustrated. Instead, we need to contemplate a world in which the nation can be multicultural, civic and ethnic, all at once. Politicians may propound a civic vision in front of a national audience but should validate competing conceptions to divergent local audiences. For instance, a Prime Minister might praise the global mix of cultures in London at one moment, the magic of integration and intermarriage the next, and still comment favourably, as did a former Prime Minister, John Major, on the settled continuity of England's villages and leafy suburbs. Each message will be eagerly received by those tuned to its frequency and ignored by most others. People generally hear what they want to hear, forming attachments to the whole in their own way.

Politicians can remain elusive about the essence of the nation, validating wide differences in the way it is perceived. Americans form attachments to different Americas: its politicians should reflect this. This makes it easier for citizens to emotionally commit to the whole, so the process becomes less forced and unnatural. A top-down approach which 
attempts to enumerate a defined set of characteristics flattens and alienates minorities who wish to maintain their culture as well as members of the ethnic majority who consider their ancestry and national identity to be seamlessly connected. Symbolism is flexible in a way power and resources are not. While states' national identity projects are buffeted by political and economic considerations, the normative aim should be to surmount this: to construct a national whole which permits a maximum of freedom while ensuring the greatest amount of solidarity. In this, multivocalism is clearly preferable to the liberal nationalist and multiculturalist alternatives.

\section{'Strong and Weak Civic Identity, and the Management of Conflict in}

\section{Liberal Societies'}

Jonathan Hearn

University of Edinburgh

The workshop asked us to consider whether: 'the nation can be seen as a way to help bridge differences and create inclusion, and, if so, how best to do this in the context of increasingly diverse societies.' Implicit here is an assumption that the problematic is being articulated in terms of the situation of characteristically 'civic' and 'liberal' forms of the nation. Some nations are premised in part on exclusion on the basis of ethnicity, religion, or ideology. However these would seem to fall outside the inquiry, 'beyond the pale'. Here we are concerned with nations that are defined less along strong and impermeable ethnic or cultural lines, and more amenable to inclusion in the first instance. Without being naïve or starry-eyed, I think we can agree that the UK and Western Europe are generally located more at the liberal/civic end of the spectrum of national forms. 
This raises the initial question: how do such nations normally achieve inclusion? Even within this broad form we can identify variations. For the rest of these remarks I will sketch two broadly recognized 'ideal types’, characteristic ways that liberal nation-states have dealt with the problem of inclusion. I will then offer a third way of thinking about this question. I treat in turn concepts of: (1) 'Strong Civic Identity’, (2) ‘Weak Civic (or civil) Identity’, and (3) liberal society as a form of 'Managed Conflict' (cf. Hall 1995).

\section{(1) 'Strong Civic Identity'}

In this model, the way is open to join the nation, but the cultural tariff is relatively high. One is expected to master the dominant language and subscribe to a core set of civic values. Among those values is likely to be the idea that society is intrinsically secular and that religion is a private matter. We might call this the 'French model'. The long-running controversy around the use of the headscarf in France is indicative (Joppke 2007, Killian 2003). In terms of social theory, we might also call it the Parsonian model, because of the way echoes Talcott Parson’s (1951) structural-functionalist conception of society as something held together by shared orientation to core values. Without in any way condoning recent atrocities committed against French people, we can observe how the attack on the staff of the magazine Charlie Hebdoe, and the slaughter in Paris on 13 November, 2015, have been articulated in public discourse not just as murderous tactics in a terrorist war, but as attacks on sacred values of the French nation and state. The response is to defend not just the French people, but moreover these defining values.

\section{(2) 'Weak Civic (or 'civil') Identity'.}

In this model, the core values are less sharply articulated, and the ethos is built more around the avoidance of conflict. A greater degree of non-integration is tolerated in terms of language, public religiosity, and so on, but this is not so much a matter of principle, as a kind of studied indifference to difference. There is a 'live and let live' attitude, and tolerance 
rather than integration is the watchword. We might call this the 'British model'. This is not to say that tensions do not arise around issues of immigration and relatively culturally unintegrated communities. It is simply that these tensions tend not to elicit the same degree of assertion of core values in response. If we were to look for an emblematic social theory to go with this model, it might be that of F. A. Hayek (2013), with its confidence that as long as certain institutions (markets, justice) are in place, diversity will take care of itself, varying needs and interests will get worked out, without the need for strong shared value orientations.

These are ideal types—neither France nor Britain conforms neatly to these 'models', and of course, aspects of both can be found in either country. Other liberal, capitalist, democratic nation-states may be more difficult to place in terms of this polarity. Both models get advanced through public education: one can promote the acquisition of core values, or the acceptance of wide differences, and to a degree, both at the same time. The underlying point is that liberalism in practice is paradoxically both a strong value and an agnosticism towards values, and this plays out differently in different historical, cultural, and

political contexts. With these ideal types I am trying to highlight a tension between the engagement and avoidance of conflict around liberal values. For the rest of these remarks I would like to suggest that more thought should be given to a third 'model', what we might call 'managed conflict'. I present this not as ‘another way of doing it', but as an argument about of how all such societies actually operate, and therefore as a set of conditions that must be taken into account.

\section{(3) 'Managed Conflict'.}

I want to suggest that an important part of what integrates liberal forms of society is not just shared values, or a pluralistic attitude towards values, but a cultural complex of conventions for channeling the inherent conflicts of interest that characterize such societies. Markets and democratic procedures channel contending claims over limited goods in 
economics and politics. Public opinion, sustained by media and other opinion forming organisations in civil society, is an arena in which ideas, beliefs, and even tastes, come into contention with one another; are proliferated and winnowed. This is a central dynamic of liberal society. Here I hark back to a classic theme in social theory—-that conflict not only disrupts, but also integrates (Simmel 1964, Gluckman 1955, Coser 1956, Collins and Annett 1975). As encoded in the British parliamentary notion of the 'loyal opposition', where actors are committed to the 'rules of the game' by which conflicts are negotiated, by which compromise is reached, conflict itself can tighten social bonds.

There are two key ways, fundamental to social structure, in which conflict gets 'managed' in liberal forms of society. First, via the public/private divide. A strong distinction here is basic to liberal societies, conjoined with the strong role of private property in the organization of the economy, and the idea of the state, in the sense of res publica, as a common public project. Along with property, many aspects of body and mind are similarly regarded as private matters, over which only the individual has domain. By having clear boundaries of domain, public and private, some issues can be rendered private matters, and effectively steered out of conflict between actors, left as matters of personal choice. But of course, this only goes so far. Much conflict will always happen around the precise definition of the boundary between private and public, and anything defined as public is potentially a focus of conflict, as diverging views of the public interest and good contend. The public/private divide is no magic solution, but it does help define more precisely where the conflicts lie. One of the key questions is to what degree ethnic and cultural differences can be channeled into the private sphere, and to what degree they necessarily impinge on the public (Rex 1997). For instance in many cases it is easier to privatize religious belief and practice, than it is to treat language use as a matter of choice in the public sphere. Conflicts around the public/private boundary do not necessarily involve cultural or ethnic differences. The 
basic tensions between left and right politics in such societies, between the respective roles of the state and the market, itself fundamentally involves understandings of this boundary. So cultural difference is just one of the things that may or may not be effectively managed by being channeled out of the public domain, or trigger debates over where the boundary properly lies.

The second key way conflict gets managed in liberal society is by incorporating groups into legitimate competitive spheres. Such societies are premised on the idea that the outcomes of competitive institutional contests are just, as long as they are fairly conducted and there is a 'level playing field'. Though some will gain and some will lose, if the means by which these outcomes are seen as valid, the wider society is correspondingly validated. Much conflict is organized around interests and values that are not cultural or ethnic. This can be in terms of (again) a left-right political spectrum, class, geographic cores and peripheries, and group affiliations with large corporate institutions, bureaucracies, and economic sectors. However cultural differences and recent immigration can become one of the factors defining conflicts over values and interests. If so, these are as legitimate a basis for political mobilization, and competition for social goods, as many others. Perhaps counterintuitively, formalizing the competition for jobs, housing, education by such groups may do more to integrate them into the system than pretending such competition doesn't exist. Full citizens 'enjoy' the right to compete with each other. Thus the generation of campaigning groups, lobbying organisations, and even political parties around ethnic group interests may be a necessary stage for bedding in conflict in the forms of more routinized competition.

One very real problem here however, is that if 'indigenous' populations (i.e. 'white’ working classes) are relatively atomised and not inclined to mobilise collectively around their class or local interests, then they may feel threatened by 'other' groups better organized around their own interests. For the binding power of regulated conflict in the form of 
competition to work, there needs to be widespread organisation into active groups mobilized around particular interests. And there need to be recognized and legitimated institutional arenas for competing for resources and negotiating conflict. My point is that liberal nationhood involves not the suppression of conflict, either by overriding core values or indulgence of difference, but the institutionalization of conflict in the form of legitimated competition.

None of this is meant to imply that liberal societies are well-oiled machines that by their nature fairly manage all social conflict. They are not. They are haphazardly evolved social forms that have elaborated certain institutions and mechanisms for managing conflict, in the context of social diversity and often shifting and weak allegiance to centralised power. Economic inequality and maldistribution of justice are chronic features of such societies, which threaten their cohesion. But as observed at the outset, they are the kind of societies that primarily concern us in regard to the present topic. They are what we have to work with. If the problem is how to build inclusive nations in the context of diversity, then answers will have to be sought by mobilising the deep structures of such societies to that purpose. Cries for shared values, or tolerance, will only go so far. Inclusion in liberal forms of society means integration into established institutions for the management of conflict.

\section{Lived nations - whose nations? The quest for belonging}

Line Nyhagen

Loughborough University

Across diverse lines of social scientific inquiry addressing privilege and disadvantage, inclusion and exclusion, belonging and alienation, an increased attention to 'the everyday' can be observed, exemplified by notions such as ‘lived citizenship’ (Lister 2003), ‘lived 
religion’ (Orsi 1997) and lived nations or ‘everyday nationhood’ (Fox and Miller-Idriss 2008). These bottom-up approaches acknowledge that people's experiences of inclusion and exclusion are context-dependent and mediated by multiple and intersecting forms of identities, loyalties and belonging (Yuval-Davis 2006). In this brief comment piece, written from the context of the United Kingdom, I argue that studies of lived nations must pay more attention to power, privilege and domination.

Within studies of nations and nationalism there has been a shift from asking about the 'when' and 'what' to the 'how' and 'where' (Antonsich 2015), but all of these interrogating terms continue to be of importance to contemporary nationhood (e.g., the when and what question was recently challenged in the context of the referendum on Scottish independence from the United Kingdom; and the how and where question is currently debated in relation to the United Kingdom’s membership status and position within the European Union).

A further key question emerging in recent scholarly literature is that of 'whose nation?' The British nation as a whole is (still) predominantly white, and the majority population continues to be invoked as the nation’s ‘we'. Findings from the 2013 British Social Attitudes survey, for example, reveal that being 'truly British’ for the survey participants means speaking English (95\%), having pre-dominantly lived in Britain (77\%), having been born in Britain (74\%), and having 'British ancestry' (51\%), where such ancestry is not explicitly defined but is likely to implicitly refer to the dominant ethnic group - whites (Kiss and Park 2014: 5; see also Kaufmann, this volume). These results indicate that people more generally (and not only those who may sympathize with the likes of Enoch Powell; see Yuval-Davis, this volume), tend to associate national belonging with common 'blood' or descent. They also illustrate a continuous process of ‘othering' of ethnic minority individuals and groups (regardless of their country of birth); supporting the perception that white people 'were here first' and thus count as 'truly British', while black and other ethnic minority people have 
subsequently arrived as visitors or guests who do not fully belong. In policy terms, the government has focused on newcomers' responsibility to adapt, to integrate and to fit in, with less attention to the majority population's willingness and ability to adapt to and welcome new citizens. As a nation, the United Kingdom remains exclusionary in both political and everyday terms via the discursive positioning of both existing ethnic minorities and new groups of migrants as 'others' who are not in a position to claim primordial belonging.

Increased academic and political attention must be paid to the ways in which patterns of power and privilege remain obstacles to an inclusive nation. Calls have been issued for scholars to consider ethnic majorities as well as ethnic minorities in studies of nations and nationalism (e.g., Skey 2013; Goode and Stroup 2015). In this regard, the notion of a minimum set of shared values, the acceptance of a 'multi-vocalist ethics of identity' and a discursively ambiguous state that caters to the interests of several stakeholders (Kaufmann, this volume) -- addresses the actual diversity of the population's lived nation, but it does not adequately deal with issues of power, privilege and inequality. A discursive repositioning of the state towards a 'constructive ambiguity' may be necessary, but it is not sufficient in order to produce socio-economic justice as well as a shared feeling of belonging.

Hearn (this volume) proposes ‘managed conflict' as a ‘third way' of working towards inclusive nations. His approach specifically acknowledges 'conflicts of interest' between groups and individuals in liberal democratic societies, including the United Kingdom. As such, it has the potential to address how different groups and individuals are situated within the multiple nexuses of advantage and disadvantage that characterize Britain. According to Hearn (this volume), liberal societies manage conflict via 'the public/private divide' and 'by incorporating groups into legitimate competitive spheres’ (ibid.). In this vision of how conflict is managed, the (corporate) state has a crucial role in that it recognizes and invites participation from economic actors (e.g., businesses and trade unions) and political actors 
(e.g., voluntary sector groups engaging in political mobilization for particular interests). What this vision omits to consider, however, is that the corporate state tends to listen to maledominated interests, while the voices and interests of women and other disadvantaged groups are often marginalized or not even heard at all. Hearn also suggests that conflict is best managed via a strict separation between the public and the private spheres, where property, as well as the body and the mind, are perceived as private, while the state is seen as a collective and public endeavor. Again, this conflict management strategy poses a problem, as it is difficult to argue and sustain a clear distinction between what is private and what is public. Women's movement activists and feminist scholars alike have long made the point that 'the personal is political' and have mobilized to politicize domestic violence, contraception, abortion, sexual intimacy and other bodily issues. What may count as private and as public is not only a gendered matter but also a matter of political contestation. Moreover, the notion that religion belongs to the private sphere (as an issue of 'the mind'), has come under critique by scholars who claim that it can play a legitimate role in democratic deliberation (e.g., Habermas 2006), and it is also being undermined by the fact that faith-based organizations deliver significant welfare services (Bäckström and Davie 2010). A strict delineation between the religious and the secular is also met with challenges by narratives that acknowledge and examine ‘the interaction of religious and Enlightenment values’ (Mack 2003: 161).

In our quest for more inclusive nations, we also need to address issues of economic and cultural justice. The question of 'whose nation?' is tied to redistribution (Fraser 1997), as exemplified by current debates about limitations to access to in-work benefits for non-UK European citizens living in the UK. It is also linked to the politics of belonging (Yuval-Davis 2006; see also Skey 2013) and to perceptions of who legitimately expresses 'true Britishness'. Privilege is thus rearticulated and reinforced in everyday expressions of nation and nationalism, or in experiences of the 'lived nation'. We need a bottom-up approach that 
examines how dominant and minoritized groups experience and live nation and nationhood. We also need a complementary top-down perspective that focuses on how the state discursively positions itself and on how the state consults with interest groups and redistributes resources to groups and individuals. What and who, when and where, are recognized as Britain and as British? Whose nation is it? In conclusion, we need to study the boundaries of belonging by focusing on patterns of disadvantage and exposing forms of exclusion, but also by interrogating forms of power, privilege and domination that continue to perpetuate the ideology of the nation and nationhood as belonging to the dominant ethnic group rather than to everyone who lives in the nation.

\section{References}

Alba, R. and Foner, N. 2014. "Comparing Immigrant Integration in North America and Western Europe: How Much Do the Grand Narratives Tell Us?" International Migration Review 48(s1): S263-S291.

Antonsich, M. 2015. "Nations and Nationalism.” In The Wiley Blackwell Companion to Political Geography, edited by J. Agnew, V. Mamadouh, A. J. Secor and J. Sharp, 297310. Malden, MA: Wiley-Blackwell.

Antonsich, M. and Matejskova, T. 2015a. "Immigration societies and the question of 'the National'." Ethnicities 15(4): 495-508.

Antonsich, M. and Matejskova, T. 2015b. “Conclusion: Nation and diversity - A false conundrum”. In Governing Through Diversity, edited by T. Matejskova and M. Antonsich, 201-209. Basingstoke: Palgrave Macmillan.

Bauer, O. (2001 [1924]) The National Question and Social Democracy. Minneapolis: University of Minnesota Press. 
Bäckström, A. and Davie G., eds. 2010. Welfare and Religion in $21^{\text {st }}$ Century Europe: Volume 1. Farnham: Ashgate.

Berger, P.L. and Luckmann, T. 1967. The Social Construction of Reality. London: Allen Lane.

Billig, M. 1995. Banal Nationalism. London: Sage.

Billig, M. 2013. Learn to Write Badly: how to succeed in the social sciences. Cambridge: Cambridge University Press.

Billig, M. 2015. “Big words in small circles: bad writing in the social sciences”. In The Future of Scholarly Writing, edited by A. Bammer and R.-E. Joeres, pp. 169-176. London: Palgrave/Macmillan.

Bloemraad, I. 2014. "Re-imagining the Nation in a World of Migration: Legitimacy, Political Claims-making and Membership in Comparative Perspective”. In Fear, Anxiety, and National Identity, edited by N. Foner and P. Simon, pp. 59-80. New York: Russell Sage Foundation Press.

Brown, G. 2006. The Future of Britishness. Speech to Fabian Society, 14 January.

Carty, R. K. 2002. "The Politics of Tecumseh Corners: Canadian Political Parties as Franchise Organizations." Canadian Journal of Political Science 35(4): 723-46.

Cohen, A.P. 1996. "Personal Nationalism: A Scottish View of Some Rites, Rights, and Wrongs." American Ethnologist 23(4): 802-815.

Collins, R. and Annett, J. 1975. Conflict Sociology: Toward and Explanatory Science. New York: Academic Press.

Coser, L.A. 1956. The Functions of Social Conflict, London: Routledge.

Durkheim, E. 2014. The division of labor in society. Simon and Schuster

Eagleton, T. 2007. Ideology. London: verso.

Edensor, T. 2002. National identity, popular culture and everyday life. Oxford: Berg. 
Fox, J. 2014. "National holiday commemorations: the view from below”. In The Cultural Politics of Nationalism and Nation-Building, edited by R. Tsang and E. Woods, 38-52. Abingdon: Routledge.

Fox, J. E. ad C. Miller-Idriss. 2008. “Everyday Nationhood.” Ethnicities 8 (4): 536-563.

Fraser, N. 1997. Justice Interruptus. Critical Reflections on the 'Postsocialist' Condition. New York: Routledge.

Goode, J. P. and Stroup, D.R. 2015. "Everyday Nationalism: Constructivism for the Masses.” Social Science Quarterly 96 (3): 717-739.

Gluckman, M. 1955. “The Peace in the Feud”. Past and Present 8: 1-14.

Greenfeld, L. (1992) Nationalism: Five Roads to Modernity. Harvard: Harvard University Press.

Habermas, J. 1992. "Citizenship and National Identity: Some Reflections on the Future of Europe." Praxis International 12: 1-19.

Habermas, J. 2006. “Religion in the public sphere.” European Journal of Philosophy 14 (1), $1-25$.

Hall, J. R. 1995. “In search of civil society”. In Civil Society: Theory, History, Comparison, edited by J. R. Hall, pp. 1-32. Cambridge: Polity.

Hayek, F.A. 2013. Law, Legislation and Liberty. London: Routledge.

Joppke, C. 2007. “State neutrality and Islamic headscarf laws In France and Germany”. Theory and Society 36(4): 313-342.

Kaufmann, E. 2006. “The Dominant Ethnic Moment.” Ethnicities 6 (2): 231-253.

Kaufmann, E. 2008. "The Lenses of Nationhood: An Optical Model of Identity." Nations \& Nationalism 14(3): 449-477.

Killian, C. 2003. “The Other Side of the Veil: North African Women in France Respond to the Headscarf Affair”. Gender and Society 17(4): 567-590. 
Kiss, Z. and Park, A. 2014. "National Identity: Exploring Britishness.” British Social Attitudes 31. Available at: http://www.bsa.natcen.ac.uk/media/38984/bsa31_national_identity.pdf (accessed 15 December 2015).

Kymlicka, W. 1995. Multicultural Citizenship: a Liberal Theory of Minority Rights. Oxford: Clarendon Press.

Lister, R. 2003. Citizenship; Feminist Perspectives. $2^{\text {nd }}$ ed. Basingstoke: Palgrave Macmillan. Mack, P. 2003. "Religion, Feminism, and the Problem of Agency: Reflections on EighteenthCentury Quakerism.” Signs 29(1): 149-177.

Mavroudi, E. 2010. "Nationalism, the Nation and Migration: Searching for Purity and Diversity." Space and Polity 14(3): 219-233.

Mihelj, S. 2011. Media nations: Communicating belonging and exclusion in the modern world. Basingstoke: Palgrave Macmillan.

Mishra, P. (2014) Nationalist Scots embody a wider dissatisfaction with our top-down world The Guardian, 30 August. Available at: http://www.theguardian.com/commentisfree/2014/aug/30/scotlands-complicity-withempire-does-not-disqualify-independence

Modood, T. 2007. Multiculturalism. A civic idea. Cambridge: Polity Press.

Orsi, R. 1997. “Everyday Miracles: The Study of Lived Religion.” In Lived Religion in America. Toward a History of Practice, edited by D. A. Hall, 3-21. Princeton: Princeton University Press.

Papademetriou, D.G. 2012. Rethinking national identity in the age of migration. Washington, DC: Migration Policy Institute. 
Park, A., Curtice. J. and Bryson, C. 2014. Being British Today: we uncover how Britain feels about itself - its boundaries, its identity, and its inhabitants. British Social Attitudes Survey: http://www.bsa-31.natcen.ac.uk/

Parsons, T. 1951. The Social System. New York: Free Press.

Powell, J. 2008. "What I Learned in Belfast." Prospect 146, May: 14

Rex, J. 1997. “The concept of multicultural society”. In The Ethnicity Reader: Nationalism, Multiculturalism and Migration, edited by Montserrat Guibernau and John Rex, pp. 217229. Cambridge: Polity.

Simmel, George. 1964. Conflict and the Web of Group Affiliations. New York: Free Press.

Skey, M. 2013. ”Why Do Nations Matter? The Struggle for Belonging and Security in an Uncertain World.” The British Journal of Sociology 64(1): 81-98.

Slaughter, S. and Rhoades. G. 2004. Academic Capitalism and the New Economy. Baltimore: Johns Hopkins University Press.

Slaughter, S. and Rhoades, G. 2009. “The academic capitalist knowledge/learning regime”. In The Exchange University, edited by A.S. Chan and D. Fisher, pp. 19-48. Vancouver: University of British Columbia Press.

Soysal, Y.N. 1994. Limits of Citizenship: Migrants and Postnational Membership in Europe. Chicago: University of Chicago Press.

Surowiecki, J. 2004. The wisdom of crowds: why the many are smarter than the few and how collective wisdom shapes business, economies, societies, and nations. New York: Doubleday.

Tamir, Y. 1993. Liberal Nationalism. Princeton: Princeton University Press.

Taylor, Charles. 1992. Multiculturalism and The Politics of Recognition. Princeton: Princeton University Press. 
Turner, V.W. 1967. The forest of symbols: aspects of Ndembu ritual. Ithaca: Cornell University Press.

Urry, John. 2005. "The complexity turn." Theory Culture \& Society 22(5): 1-14.

Yuval-Davis, N. 2006. "Belonging and the Politics of Belonging.” Patterns of Prejudice 40(3): 197-214.

Yuval-Davis, N. (2011) The Politics of Belonging: Intersectional Contestations. Thousands Oaks, CA: Sage.

Wimmer, A. and Glick Schiller, N. 2002. "Methodological nationalism and beyond: nationstate building, migration and the social sciences." Global Networks 2(4): 301-334.

\footnotetext{
${ }^{\mathrm{i}}$ The term constructive ambiguity is credited to Henry Kissinger and is often used in peace negotiations (Powell 2008)
} 